\section{Pacific Northwest}

National Laboratory

Operated by Battelle for the

U.S. Department of Energy

\title{
Ultrasonic Examination of Double-Shell Tank 241-AN-103 Examination Completed October 2005
}

AF Pardini

GJ Posakony

January 2006

Prepared for the U.S. Department of Energy under Contract DE-AC05-76RL01830 


\title{
DISCLAIMER
}

This report was prepared as an account of work sponsored by an agency of the United States Government. Neither the United States Government nor any agency thereof, nor Battelle Memorial Institute, nor any of their employees, makes any warranty, express or implied, or assumes any legal liability or responsibility for the accuracy, completeness, or usefulness of any information, apparatus, product, or process disclosed, or represents that its use would not infringe privately owned rights. Reference herein to any specific commercial product, process, or service by trade name, trademark, manufacturer, or otherwise does not necessarily constitute or imply its endorsement, recommendation, or favoring by the United States Government or any agency thereof, or Battelle Memorial Institute. The views and opinions of authors expressed herein do not necessarily state or reflect those of the United States Government or any agency thereof.

\author{
PACIFIC NORTHWEST NATIONAL LABORATORY \\ operated by \\ BATTELLE \\ for the \\ UNITED STATES DEPARTMENT OF ENERGY \\ under Contract DE-AC05-76RL01830
}

Printed in the United States of America
Available to DOE and DOE contractors from the Office of Scientific and Technical Information,
P.O. Box 62, Oak Ridge, TN 37831-0062;
ph: (865) 576-8401
fax: $(865)$ 576-5728
email: reports@adonis.osti.gov

\begin{abstract}
Available to the public from the National Technical Information Service, U.S. Department of Commerce, 5285 Port Royal Rd., Springfield, VA 22161 ph: (800) 553-6847 fax: $(703) 605-6900$ email: orders@ntis.fedworld.gov online ordering: http://www.ntis.gov/ordering.htm
\end{abstract}

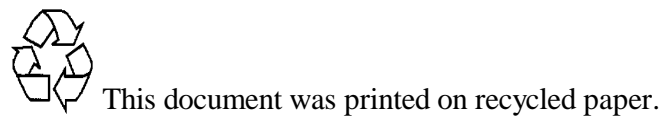


PNNL-15603 Rev. 0

\title{
Ultrasonic Examination of Double-Shell Tank 241-AN-103 \\ Examination Completed October 2005
}

\author{
AF Pardini \\ GJ Posakony
}

January 2006

Prepared for the U.S. Department of Energy under Contract DE-AC05-76RL01830

Pacific Northwest National Laboratory

Richland, Washington 99352 


\section{Summary}

COGEMA Engineering Corporation (COGEMA), under a contract from CH2M Hill Hanford Group (CH2M Hill), has performed an ultrasonic nondestructive examination of selected portions of DoubleShell Tank 241-AN-103. The purpose of this examination was to provide information that could be used to evaluate the integrity of the wall of the primary tank. The requirements for the ultrasonic examination of Tank 241-AN-103 were to detect, characterize (identify, length size, and locate), and record measurements made of any circumferential wall cracks that might be present in the lower portion of the primary tank knuckle region. Any measurements that exceed the requirements set forth in the Engineering Task Plan (ETP), RPP-22571 (Jensen 2004) and summarized on page 1 of this document, are reported to CH2M Hill and the Pacific Northwest National Laboratory (PNNL) for further evaluation. Under the contract with $\mathrm{CH} 2 \mathrm{M}$ Hill, all data is to be recorded on electronic media and paper copies of all measurements are provided to PNNL for third-party evaluation. PNNL is responsible for preparing a report that describes the results of the COGEMA ultrasonic examinations.

\section{Examination Results}

The results of the examination of Tank 241-AN-103 have been evaluated by PNNL personnel. The ultrasonic examination consisted of one approximately 20-ft long scan around the circumference of the primary tank lower knuckle region. The examination was performed to detect any circumferential cracking that may be present in the lower portion of the primary tank knuckle region.

\section{Primary Tank Wall Knuckle Scan Paths}

The upper portion of the knuckle area of the primary tank was scanned utilizing the Y-arm scanner attached to the AWS-5D crawler. The Y-arm scans the transducer down around the knuckle approximately 8-in. from a starting position 2-in. below the upper knuckle weld joining Plate \#5 to the knuckle. The remaining distance between the transducer and the lower knuckle weld joining the bottom plate is interrogated utilizing a multiple $\mathrm{V}$ path technique qualified for the extended $\mathrm{Y}$-arm scanner. (Pardini 2005) The lower portion of the knuckle was examined for cracks oriented circumferentially around the primary tank. No circumferentially oriented crack-like indications were detected in the lower portion of the primary tank knuckle area. 


\section{Contents}

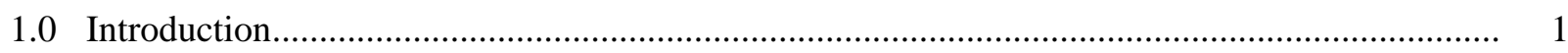

2.0 Qualified Personnel, Equipment, and Procedure ......................................................... 2

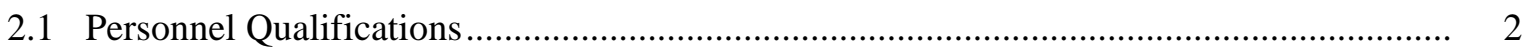

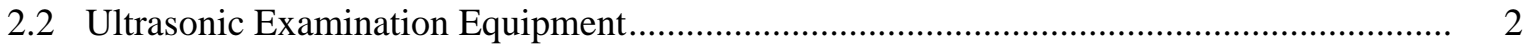

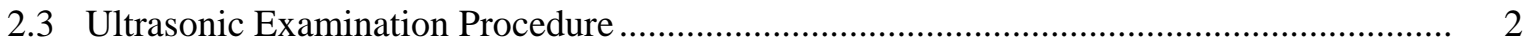

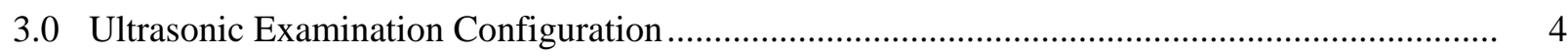

3.1 Primary Tank Wall Knuckle Area Transducer Configuration ........................................... 4

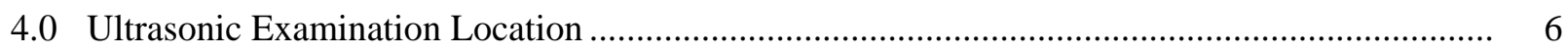

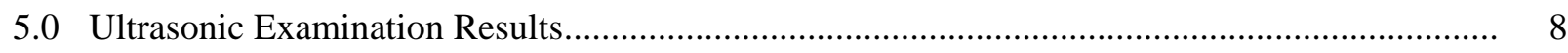

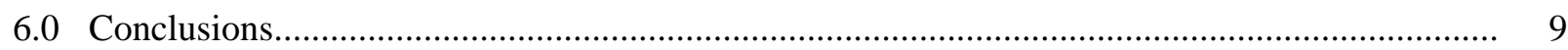

6.1 Primary Tank Wall Knuckle Scan Paths .................................................................. 9

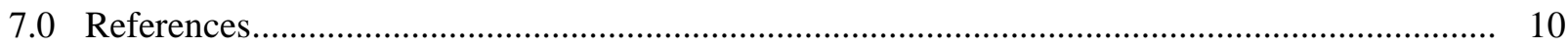




\section{Figures}

3.1 Lower Section of the Knuckle Examined ….............................................................. 4

3.2 Sketch of the Lower Section of the Knuckle Examined with the Y-Arm Scanner ................. 5

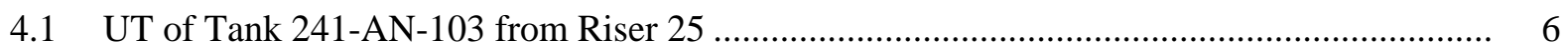

4.2 Sketch of Scan Paths on Tank 241-AN-103 ................................................................... 7 


\subsection{Introduction}

COGEMA Engineering Corporation (COGEMA), under a contract from CH2M Hill Hanford Group (CH2M Hill), has performed an ultrasonic nondestructive examination (UT) of selected portions of Double-Shell Tank (DST) 241-AN-103. The purpose of this examination was to provide information that could be used to evaluate the integrity of the DST. The requirements for the UT of Tank 241-AN-103 were to detect, characterize (identify, length size, and locate), and record measurements made of any circumferential wall cracks that might be present in the lower portion of the primary tank knuckle region. Any measurements that exceed the requirements set forth in the Engineering Task Plan (ETP), RPP22571 (Jensen 2004), are reported to CH2M Hill and the Pacific Northwest National Laboratory (PNNL) for further evaluation. Specific measurements that are reported include the following:

- Stress-corrosion cracks that are detected in the tank knuckle.

The accuracy requirements for ultrasonic measurements for this type of defect are as follows:

- Location - locate all reportable indications within \pm 1.0 -in.

Under the contract with $\mathrm{CH} 2 \mathrm{M}$ Hill, all data is to be recorded on electronic media and paper copies of all measurements are provided to PNNL for third-party evaluation. PNNL is responsible for preparing a report that describes the results of the COGEMA UT. 


\subsection{Qualified Personnel, Equipment, and Procedure}

Qualification of personnel participating in the DST inspection program, the UT equipment (instrument and mechanical scanning fixture), and the UT procedure that will be used in the examination of the current DST is required by $\mathrm{CH} 2 \mathrm{M}$ Hill. Personnel participating in the examinations are to be certified in accordance with the American Society for Nondestructive Testing (ASNT) Guideline SNTTC-1A-92 and associated documentation is to be provided. The capability of the UT system is to be validated through a performance demonstration test (PDT) administered by PNNL on a mock-up simulating the actual DST. The current procedure for the UT is to be based on requirements listed in the American Society for Mechanical Engineers (ASME), Boiler and Pressure Vessel Code Section V, Article 4, Ultrasonic Examination Methods for Inservice Inspection.

\subsection{Personnel Qualifications}

The following individual was qualified and certified to perform UT of the Hanford DST 241-AN-103:

- Mr. Wesley H. Nelson, ASNT Level III (\#LM-1874) in UT, has been identified as COGEMA's UT Level III authority for this project. Mr. Nelson has been certified by COGEMA as a UT Level III in accordance with COGEMA procedure COGEMA-SVCP-PRC-014, latest revision which conforms to the requirements of ASNT SNT-TC-1A, 1992. Further documentation has been provided to establish his qualifications. (Pardini 2000) (Pardini 2005).

\subsection{Ultrasonic Examination Equipment}

$\mathrm{CH} 2 \mathrm{M}$ Hill has provided the UT equipment for the examination of Tank 241-AN-103. This equipment consists of a Force Institute P-Scan ultrasonic test instrument and a Force Institute AWS-5D remote-controlled, magnetic-wheel crawler for examining the lower portion of the primary tank knuckle region. The examination of Tank 241-AN-103 included utilization of the Y-arm scanning bridge. Ultrasonic transducers used for the examinations are commercial off the shelf. The P-Scan ultrasonic system and Y-arm scanner attachment have been qualified through a PDT administered by PNNL. (Posakony and Pardini 1998)

\subsection{Ultrasonic Examination Procedure}

COGEMA has provided the UT procedure for the examination of Tank 241-AN-103. This procedure, COGEMA-SVUT-INS-007.3, Revision 3, outlines the type of UT and mechanical equipment that are to be used as well as the types of transducers. Only angle-beam transducers are used for the examination of the lower portion of the primary tank knuckle region. The examination procedures include full documentation on methods for calibration, examination, and reporting. Hard copies of the P-Scan (projection or angle beam) views of all areas scanned are made available for analysis. The UT procedure requires the use of specific UT transducers for the different examinations. A calibration performed before 
and after the examinations insures that each transducer used in the inspection is adjusted and that the entire system is performing correctly. The COGEMA UT procedure has been qualified through a PDT. Revisions to the procedure are reviewed to determine if a further PDT is required. (Posakony and Pardini 1998) (Pardini 2005) 


\subsection{Ultrasonic Examination Configuration}

COGEMA is required to inspect selected portions of the DSTs which may include the primary and secondary tank walls, the HAZ of the primary tank vertical and horizontal welds, and the tank knuckle and bottoms. The P-Scan system has been configured to perform these examinations and has been performance tested. The examination of Tank 241-AN-103 included only the UT of the lower portion of the primary tank knuckle region.

\subsection{Primary Tank Wall Knuckle Area Transducer Configuration}

Examination of the knuckle utilizes a modified scanning bridge known as the Y-arm scanner. The Y-arm provides scanning of the transducers directly on the knuckle region. The Y-arm is a special fixture that attaches to the AWS-5D magnetic wheel crawler. Its purpose is to extend the reach of the transducer assembly. This extension allows the transducer assembly to follow the curve of the upper portion of the knuckle below the transition Plate \#5 to upper knuckle weld. It is designed to hold the dual 0-degree or two 45-degree transducers in the same configuration as used for the examination of the tank wall. The transducer configuration used for crack detection in this examination was a single 45-degree angle-beam transducer oriented in the axial direction. This configuration is designed to detect cracks that are in a circumferential direction with respect to the axis of the tank. Figure 3.1 is a sketch showing the section of the knuckle examined using the Y-arm fixture. With the transducer positioned 2-in. below the transition Plate \#5 to upper knuckle weld, the scanning bridge was set to scan the transducer downward an additional distance of approximately 8-in. in 0.035-in steps (or as set by the UT inspector). The remaining distance between the transducer and the lower knuckle weld joining the bottom plate is interrogated utilizing a multiple $\mathrm{V}$ path technique qualified for the extended Y-arm scanner. (Pardini 2005)

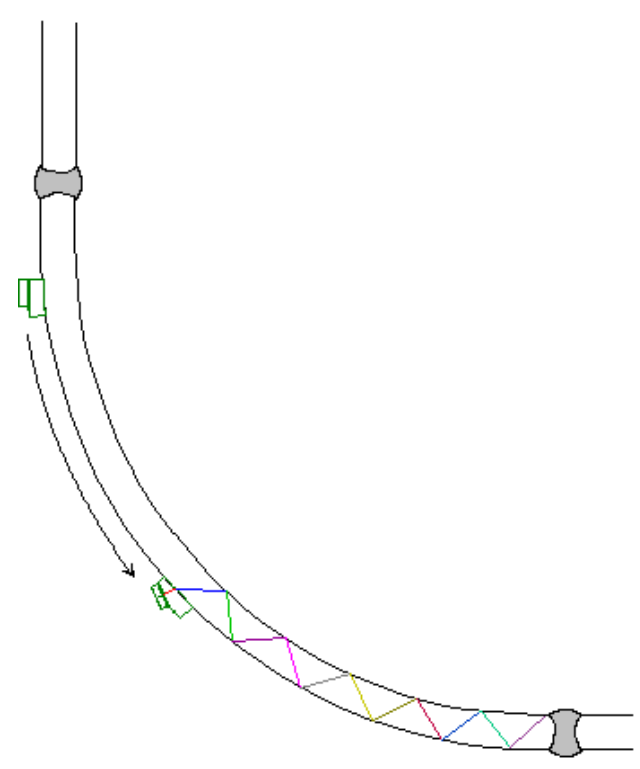

Transducer Specifications:

Angle-Beam

Type: MWB-45 04E

Frequency: $4 \mathrm{MHz}$

Size: 8 X $9 \mathrm{~mm}$

Manufacturer: Krautkramer

Figure 3.1 Lower Section of the Knuckle Examined 
Upon completion of the single line scan, the bridge was indexed circumferentially 0.035 -in. (or as set by the UT inspector) and the scan downward is repeated to obtain a pixel size 0.035 -in. $\mathrm{x} 0.035$-in. This scan pattern continued for approximately 20-ft. circumferentially as shown in Figure 3.2.

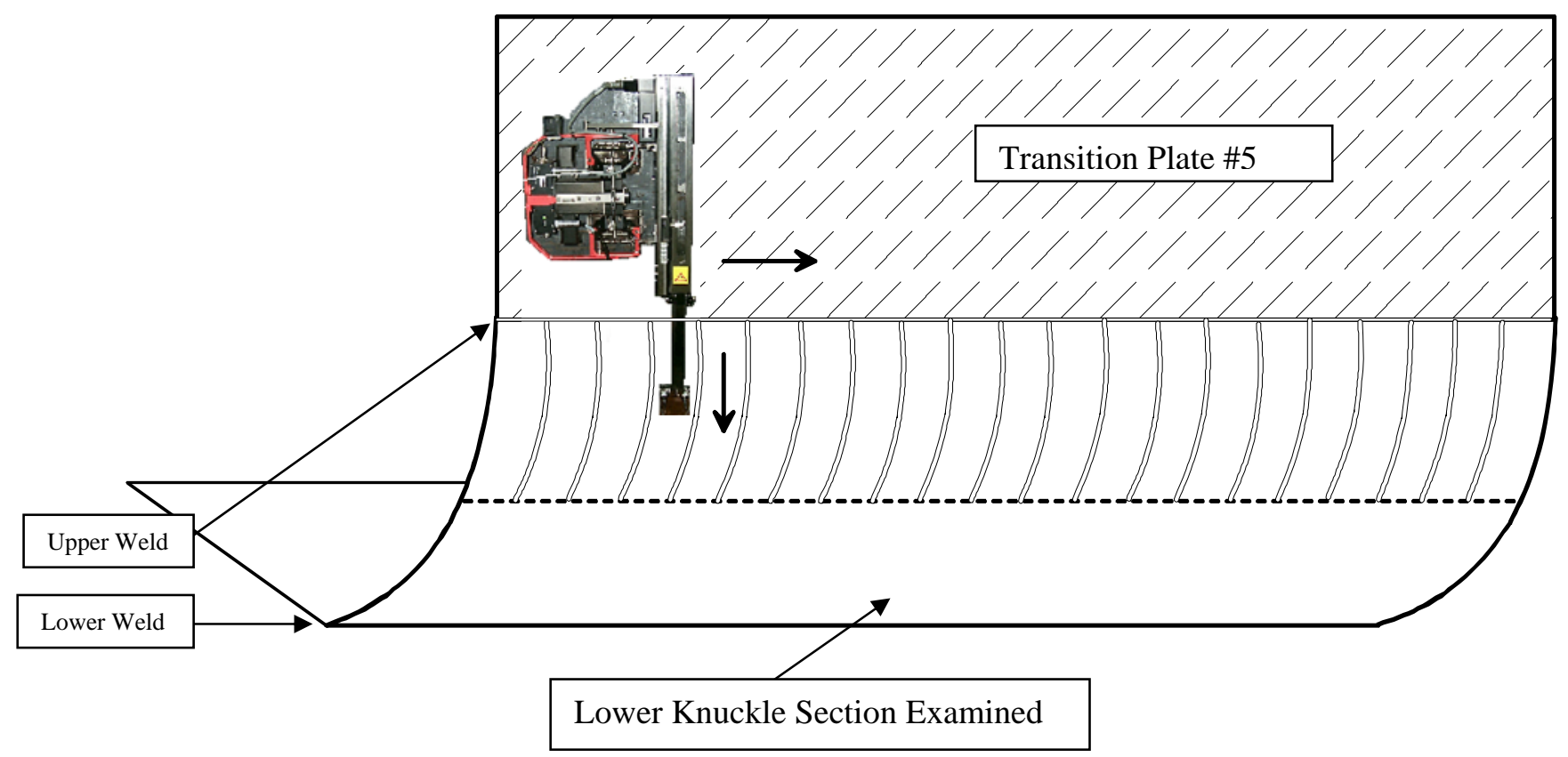

Figure 3.2. Sketch of the Lower Section of the Knuckle Examined with the Y-Arm Scanner 


\subsection{Ultrasonic Examination Location}

Tank 241-AN-103 is located in the Hanford 200 East area in AN Tank Farm. The crawler and associated scanner that hold the transducers were lowered into the 24-in. riser located on the north side of 241-AN-103 and designated as Riser 25. Figure 4.1 provides a graphic of the location of this riser.

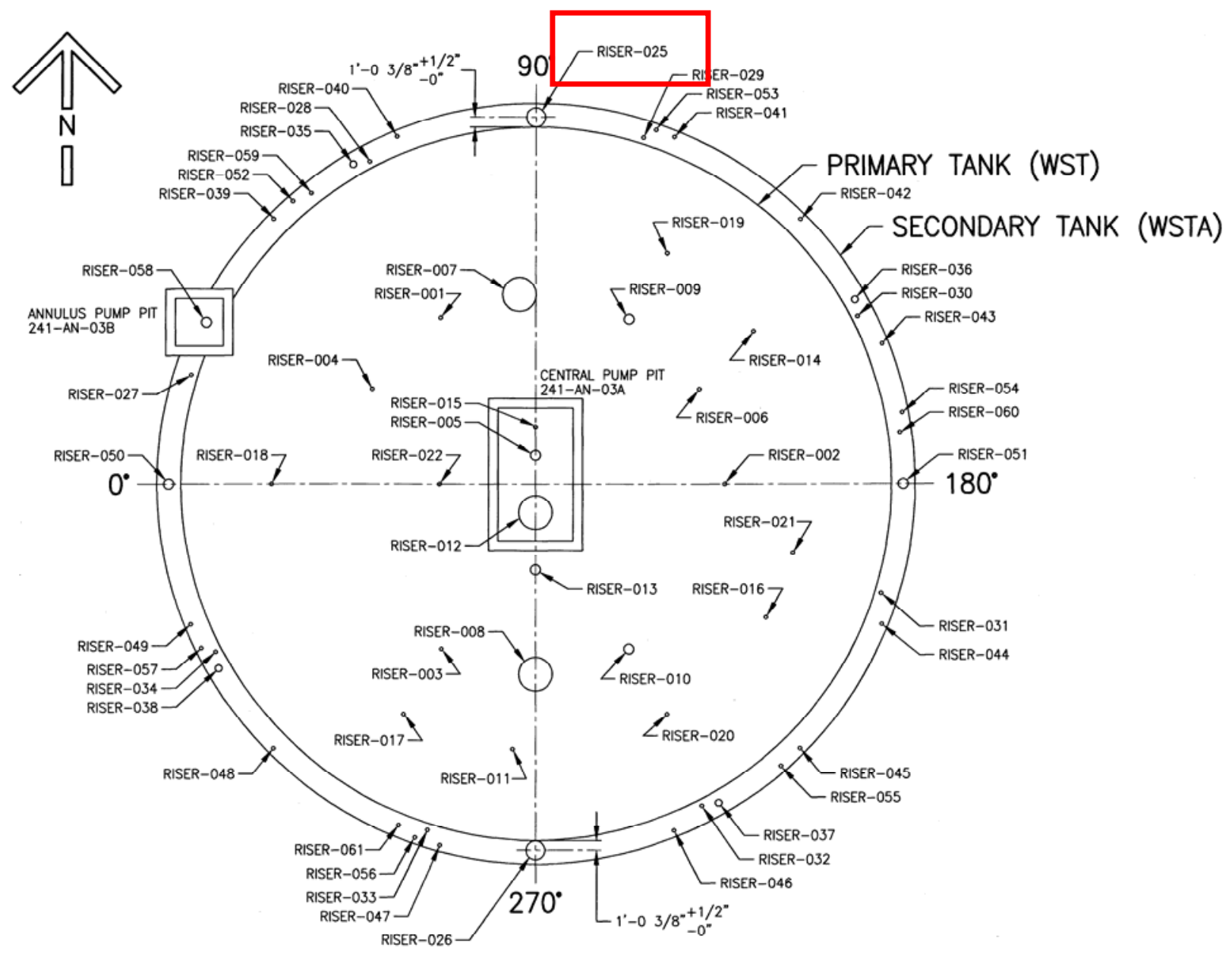

PLAN VIEW TANK 241-AN-103

Figure 4.1. UT of Tank 241-AN-103 from Riser 25 
Figure 4.2 describes the areas on the primary wall of Tank 241-AN-103 that were ultrasonically examined. The ultrasonic examination consisted of one approximately $20-\mathrm{ft}$ long scan around the circumference of the primary tank lower knuckle region. The examination was performed to detect any circumferential cracking that may be present in the lower portion of the primary tank knuckle region.

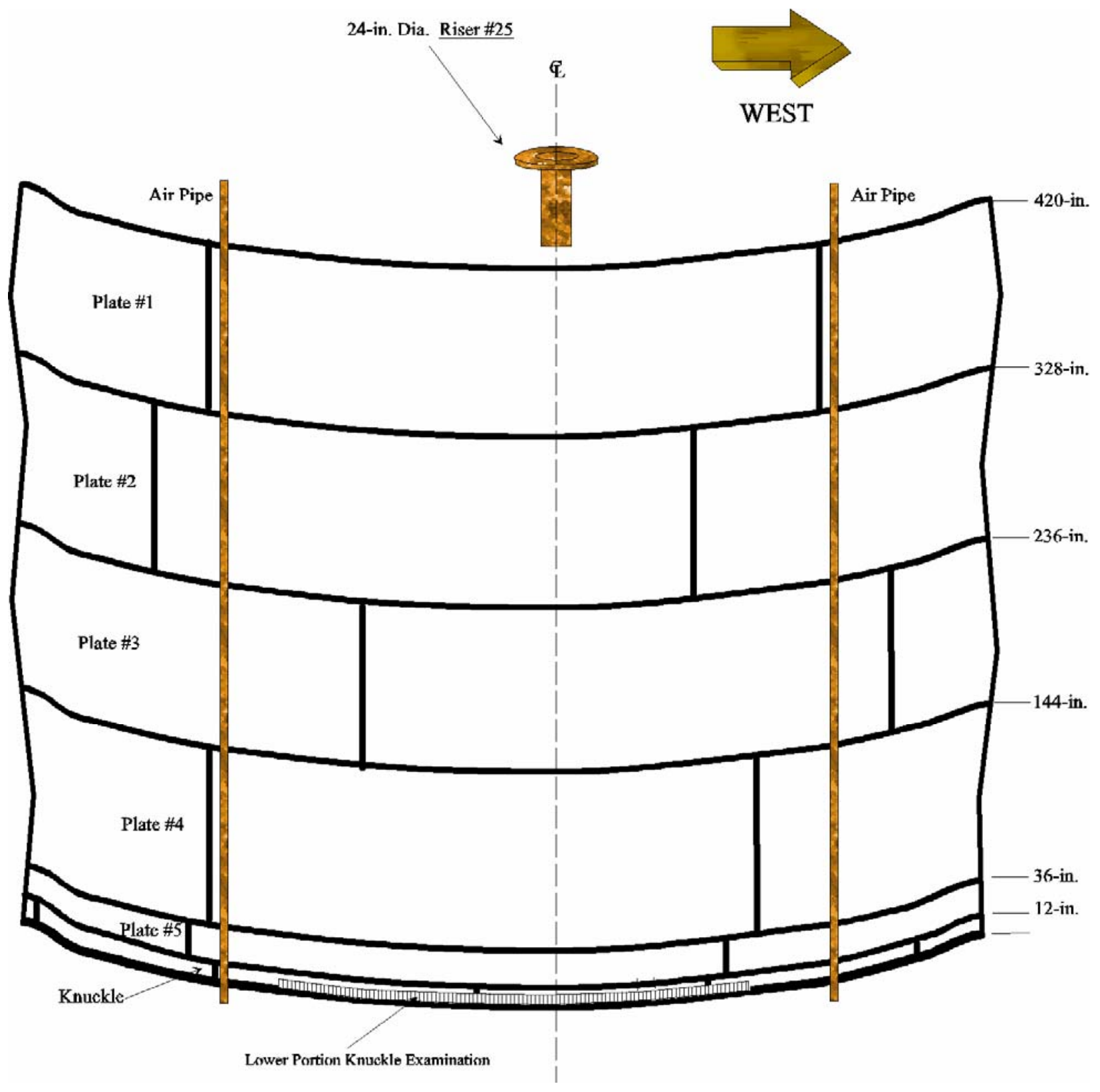

Figure 4.2. Sketch of Scan Paths on Tank 241-AN-103 


\subsection{Ultrasonic Examination Results}

COGEMA has provided detailed reports, including P-Scan hard copies of all areas that were ultrasonically examined, to PNNL for third-party review. The data was acquired and analyzed by COGEMA Level III Mr. Wes Nelson. The results of the examination of Tank 241-AN-103 showed no indication of cracking present in the approximately $20-\mathrm{ft}$. of lower knuckle area examined. 


\subsection{Conclusions}

The results of the examination of Tank 241-AN-103 have been evaluated by PNNL personnel. The ultrasonic examination consisted of one approximately 20-ft long scan around the circumference of the primary tank lower knuckle region. The examination was performed to detect any circumferential cracking that may be present in the lower portion of the primary tank knuckle region.

\subsection{Primary Tank Wall Knuckle Scan Paths}

The upper portion of the knuckle area of the primary tank was scanned utilizing the Y-arm scanner attached to the AWS-5D crawler. The Y-arm scans the transducer down around the knuckle approximately 8-in. from a starting position 2-in. below the upper knuckle weld joining Plate \#5 to the knuckle. The remaining distance between the transducer and the lower knuckle weld joining the bottom plate is interrogated utilizing a multiple $\mathrm{V}$ path technique qualified for the extended $\mathrm{Y}$-arm scanner. (Pardini 2005) The lower portion of the knuckle was examined for cracks oriented circumferentially around the primary tank. No circumferentially oriented crack-like indications were detected in the lower portion of the primary tank knuckle area. 


\subsection{References}

Jensen, C. E., 2004, Engineering Task Plan for the Ultrasonic Inspection of Hanford Double-Shell Tanks FY2005, RPP-22571, Rev 0, September 2004, CH2M Hill Hanford Group, Inc., Richland, Washington.

A. F. Pardini to C.E. Jensen dated August 22, 2000, Letter Report on Performance Demonstration Test PDT, May 2000. Pacific Northwest National Laboratory, Richland, Washington. Copy on file in the PNNL DST Project Records.

Posakony GJ and AF Pardini. 1998. Final Report - Ultrasonic Examination of Double-Shell Tank 241AN-107, PNNL-11971, Pacific Northwest National Laboratory, Richland, Washington.

A. F. Pardini to C.E. Jensen dated September 13, 2005, Letter Report P-Scan System Lower Knuckle Detection Only Performance Demonstration Test (Wesley Nelson). Pacific Northwest National Laboratory, Richland, Washington. Copy on file in the PNNL DST Project Records.

A. F. Pardini to C.E. Jensen dated September 21, 2001, Letter Report Qualification of the Y-Arm Attachment Pacific Northwest National Laboratory, Richland, Washington. Copy on file in the PNNL DST Project Records. 


\section{Distribution}

No. of

Copies

Onsite

2 Hanford Site
J. L. Castleberry (1)
R3-26
D. E. Bowers (1)
S5-07

8 Pacific Northwest National Laboratory
S. L. Crawford (1)
$\mathrm{K} 5-26$
A. F. Pardini (5)
K5-26
G. J. Posakony (1)
K5-26
M. L. Watkins (1)
K5-26 